\title{
Vertical zonation of the Siberian Arctic benthos: bathymetric boundaries from coastal shoals to deep-sea Central Arctic
}

\author{
Andrey Vedenin ${ }^{\text {Corresp., } 1}{ }^{,}$, Sergey Galkin ${ }^{2}$, Alexander Mironov ${ }^{2}$, Andrey Gebruk ${ }^{2}$ \\ ${ }^{1}$ Laboratory of Plankton Communities Structure and Dynamics, Shirshov Institute of Oceanology, Russian Academy of Sciences, Moscow, Moscow, Russia \\ 2 Laboratory of Ocean Bottom Fauna, Shirshov Institute of Oceanology, Russian Academy of Sciences, Moscow, Moscow, Russia \\ Corresponding Author: Andrey Vedenin \\ Email address: urasterias@gmail.com
}

The bathymetric distribution of species of Annelida, Crustacea and Echinodermata from the region including the Kara, Laptev and East Siberian seas and the adjacent region of the deep-sea Central Arctic was analysed. We focused on vertical species ranges revealing zones of crowding of upper and lower species range limits.

Using published data and in part the material obtained during the expeditions of the P.P. Shirshov Institute of Oceanology, we evaluated species vertical distribution from $0 \mathrm{~m}$ to the maximum depth of the Central Arctic ( 4400 m). The entire depth range was divided into smaller intervals; number of upper and lower limits of species depth ranges was counted and plotted to visualize the range limits crowding.

Several zones of crowding of vertical species range limits were found for all analysed macrotaxa. The most significant zones occurred at depths of 450-800 $\mathrm{m}$ and 1800-2000 m. The first depth zone corresponds to the boundary between the sublittoral and bathyal faunas. The last one marks the boundary between the bathyal and abyssal faunas. Depths of these boundaries differ from those reported from other Ocean regions; possible explanations of these differences are discussed. 


\section{Vertical zonation of the Siberian Arctic benthos:}

2 bathymetric boundaries from coastal shoals to deep-

3 sea Central Arctic

4

5

6

7

8

9

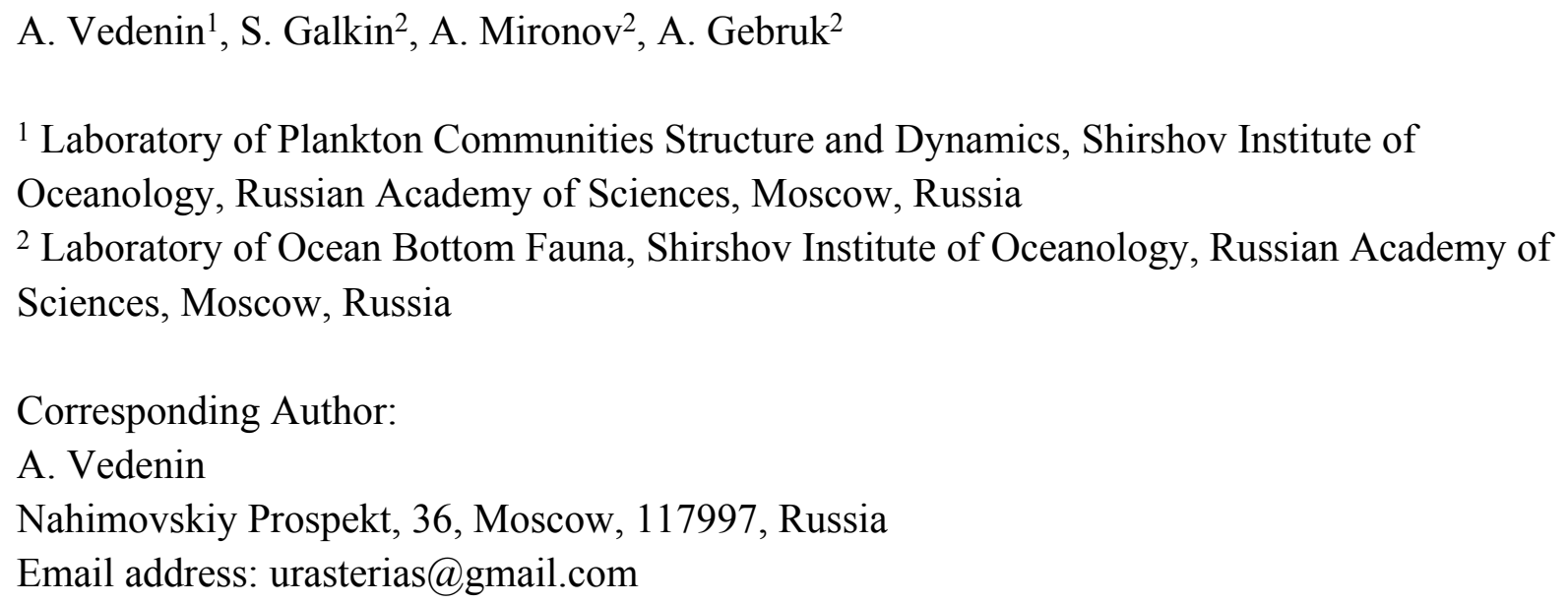

\section{Abstract}

The bathymetric distribution of species of Annelida, Crustacea and Echinodermata from the region including the Kara, Laptev and East Siberian seas and the adjacent region of the deep-sea Central Arctic was analysed. We focused on vertical species ranges revealing zones of crowding of upper and lower species range limits.

Using published data and in part the material obtained during the expeditions of the P.P. Shirshov Institute of Oceanology, we evaluated species vertical distribution from $0 \mathrm{~m}$ to the maximum depth of the Central Arctic $(\sim 4400 \mathrm{~m})$. The entire depth range was divided into smaller intervals; number of upper and lower limits of species depth ranges was counted and plotted to visualize the range limits crowding.

Several zones of crowding of vertical species range limits were found for all analysed macrotaxa. The most significant zones occurred at depths of 450-800 $\mathrm{m}$ and $1800-2000 \mathrm{~m}$. The first depth zone corresponds to the boundary between the sublittoral and bathyal faunas. The last one marks the boundary between the bathyal and abyssal faunas. Depths of these boundaries differ from those reported from other Ocean regions; possible explanations of these differences are discussed. 


\section{Introduction}

36 Vertical zonation of marine fauna has been the subject of repeated interest over many years. In 37 published schemes of vertical zonation many authors recognised the major boundary at $\sim 200 \mathrm{~m}$, the border between the sublittoral and the bathyal zoned (Belyaev et al., 1959; Vinogradova, 1962; Carney et al., 1983; Mironov, 1986; Howell et al., 2002; Thistle, 2003; Carney, 2005; Jamieson, 2015). Watling et al. (2013) re-examined the biogeographic classification of depth ranges in the deep sea and suggested that this boundary lies deeper, at $300 \mathrm{~m}$. The second major vertical division is the border between the bathyal and abyssal. In the scheme of the vertical zonation suggested by Belyaev et al. (1959), the bathyal is defined as a depth zone between 200 $\mathrm{m}$ and $3000 \mathrm{~m}$, with a zone between $2500 \mathrm{~m}$ and $3500 \mathrm{~m}$ considered as the transition between the bathyal and abyssal zones. The boundary at $\sim 3000 \mathrm{~m}$ was demonstrated in a number of publications (Vinogradova, 1962; Krayushkina, 2000; Howell et al., 2002; Gebruk et al., 2010), however some authors recognised the border between the bathyal and abyssal closer to $2000 \mathrm{~m}$ (Gage \& Tyler, 1991; Thistle, 2003) or 4000m (Thurman, 1985). In classification of Watling et al. (2013), the "upper bathyal" at 300-800 $\mathrm{m}$ and the "lower bathyal" at 800-3500 $\mathrm{m}$ were reported as separate zones.

Schemes of vertical zonation with universal boundaries at the same depth throughout the Ocean indicate only "average" depths of boundaries (Hedgpeth, 1957; Belyaev et al., 1959; Vinogradova, 1962; Gage \& Tyler, 1992; Thistle, 2003; Watling et al., 2013). In reality, depths of vertical zones significantly vary from one region to another. Thus, boundaries at different depths depending on a region were shown for a number of macrotaxa based on the same method. Among the examples are the asellote isopods (Menzies et al., 1973) and the echinoids (Mironov, 1986), though these studies were performed outside the Arctic. The Arctic Ocean markedly differs from other areas in the vertical biodiversity trends. Outside the Arctic, a parabolic trend of benthic diversity is observed with peak values at $2000-3000 \mathrm{~m}$ (Rex \& Etter, 2010). In the Kara, Laptev and East-Siberian Seas the peak of species richness occurs at approximately $100 \mathrm{~m}$, in the Barents Sea - slightly deeper 100 m (Anisimova, 1989; Stepanjants, 1989; Vassilenko, 1989; Vedenin et al., 2018), whereas in the Chukchi Sea - shallower $100 \mathrm{~m}$ (Golikov, 1989; Stepanjants, 1989; Vassilenko, 1989).

Schemes of vertical zonation are not always comparable because methods and approaches used by different authors vary significantly and sometimes fundamentally. Moreover, approaches 
66 to zonation are not always clearly explained. The variety of approaches to define vertical zones

67 in the Ocean was examined and structured by Golikov et al. (1990) and Mironov (2013), who 68 distinguished three main approaches to marine biogeography differing in the subject of study and 69 methods. The first approach deals with species range limits, named "biotic" (or "faunistic") 70 approach, according to classification of Mironov (2013). The second one is the "biocenotic" 71 approach, it deals with communities (or biocenoces). The third approach is the "landscape", it 72 considers environmental parameters.

73 According to Mironov (2013), in the biotic approach the main criterion of a biogeographic 74 boundary (=biotic boundary) is a zone of crowding of species range limits. In case of vertical 75 zonation, depth ranges of crowding of upper or lower limits of species vertical ranges are 76 considered. This approach was used in different Ocean regions on the example of various 77 invertebrate macrotaxa and fish (Backus, 1965; Carney et al., 1983; Gage et al., 1984; Mironov, 78 1986; Gage \& Tyler, 1992). In the biocenotic approach the criterion of a boundary is a difference 79 between local biotas commonly revealed using cluster analysis (based on such parameters as 80 species diversity, abundance and biomass) (Longhurst, 1985; Grassle \& Morse-Porteous, 1987; 81 Rex \&Etter, 2010). In the landscape approach boundaries usually correspond to sharp gradients 82 of physical-chemical parameters (Milkov, 1970; Deacon, 1982; Gukov, 1999; Watling et al., 83 2013). based on the biocenotic (community-based) or mixed (based on methods with certain elements of biotic, biocenotic and landscape) approaches. Published data mainly relate to the Kara Sea 87 (Filatova \& Zenkevich, 1957; Antipova \& Semyonov, 1989; Jørgensen et al., 1999; Anisimova, 88 2003; Deubel et al., 2003; Galkin \& Vedenin, 2015; Vedenin et al., 2015), in part to the Laptev Sea (Fütterer, 1994; Sirenko et al., 2004), the East Siberian Sea (Gukov et al., 2005; Sirenko \& Denisenko, 2010) with a few studies dealing with the deep-sea Central Arctic (Deubel, 2000; Vedenin et al., 2018; Rybakova et al., 2019).

The Norwegian and Greenland seas are the closest to the Siberian Arctic where the biotic 93 (species-based) approach was applied (Zhirkov \& Mironov, 1985; Svavarsson et al., 1990; 94 Krayushkina, 2000; Oug et al., 2017). Several zones of crowding of bathymetric limits were 95 shown: at depths 450-700 m, 900-1000 m and 2000 m for Annelida (Zhirkov \& Mironov, 1985; 96 Oug et al., 2017), 150-200 $\mathrm{m}$ and 1100-1200 $\mathrm{m}$ for Asteroidea and 600-800 $\mathrm{m}$ for Holothuroidea 
97 (Krayushkina, 2000). These depth ranges (except 150-200 $\mathrm{m}$ fro Asteroidea) differ from those 98 shown for other parts of the Ocean. However, even in the Norwegian Sea (one of the best studied regions of the Arctic Ocean) the zones of crowding matched depth ranges with the highest number of samples (Zhirkov \& Mironov, 1985) suggesting a bias related to the sampling effort.

In the present study we tried to collect all available data for the Siberian Arctic on the 102 bathymetric distribution of three macrotaxa: Annelida, Crustacea and Echinodermata. We aimed at examining the upper and lower vertical limits of species ranges (in these macrotaxa) to reveal the depth of limits crowding marking potential biogeographic boundaries. We hypothesized that 105 the boundaries between the sublittoral and bathyal, and between the bathyal and abyssal faunas exist in the Arctic, but are at located at depths different from those in other ocean areas.

107

108

\section{Materials \& Methods}

The study area included the Kara Sea, Laptev Sea, East Siberian Sea and the adjacent sector of the Central Arctic (Fig. 1). The area marked as "the Central Arctic" in Fig. 1 is bordered by dashed lines since we also considered species recorded from adjacent areas owing to supposed uniformity of fauna of central Arctic basins (Bluhm et al., 2010).

Data on the bathymetric ranges of Annelida, Crustacea and Echinodermata were previously published in Data in Brief (Vedenin et al., 2021). From all listed species in these three macrotaxa, we selected about two thirds "most reliable": 166 from 253 species of Annelida; 372 from 464 species of Crustacea and 51 from 63 species of Echinodermata. The selection was based on the following criteria:

- Species distribution. Species known only from borders of basins (e.g. from the western-most Kara Sea or the eastern-most East Siberian Sea) were excluded from the analysis.

- Number of findings. At least two known depth records from the study area were required.

- Taxonomy problems. Taxa with questionable taxonomical status (e.g. taxon inquirendum or unresolved species complexes) were excluded from the analysis.

- Overall reliability of published information. We used mostly publications focused on the taxonomy, since there is a higher likelihood of identification mistakes in ecological publications.

The complete species list used for the analysis is presented in the Supplementary 1. The procedure we used after compiling the list of species records was based on methods described by 
128 Vinogradova (1962) and Mironov (1986, 2013). Important characteristics of the biotic approach 129 are the total exclusion of environmental data from primary analysis and the assumption of the 130 continuity of a species range (including the bathymetric range). Disjunctions in the distribution 131 of species are disregarded (Mironov, 2013).

132 The entire depth range of sampling (from 0 to $4400 \mathrm{~m}$ ) was divided into 200-m intervals. In 133 addition, the upper $800 \mathrm{~m}$ horizon was divided into 50-m intervals. The number of upper and 134 lower limits of species depth ranges within each $200 \mathrm{~m}$ - or $50 \mathrm{~m}$-interval was counted and 135 plotted as a linear graph.

136 The observed number of vertical limits was compared to the expected one, calculated using 137 the equation suggested by Backus et al. (1965). In the original paper, the vertical zonation of 138 mesopelagic fishes was studied based on the Isaacs-Kidd trawl samples at subsequent depth 139 ranges. The Backus model proposes that the expected number of species in each of the 140 subsequent depth intervals will remain constant if no biogeographic boundaries are present 141 (Backus et al., 1965; Gage, 1986). In the upper-most depth range (the first haul) all species will 142 be met the first time (the number of species sampled = the number of upper limits within the 143 upper depth range). The likelihood of meeting for the last time each sampled species will be 144 increasing respectively in each of the next, deeper depth ranges. The Backus regularity can be 145 expressed as the following equation: $a_{s}(x)=k-\frac{k}{N} \sum_{n=0}^{x-1} a_{s}(n)$, where $a_{s}(x)$ - number of upper 146 species limits within the $x$ depth interval; $k$-number of species occurring in each $x$ depth 147 interval presumed in the model as constant; $N$ - total number of species, occurring in the entire 148 depth range; $\sum_{n=0}^{x-1} a_{s}(n)$ - sum of the upper limits, calculated in previous depth intervals. The 149 lower limits of species distribution can be calculated similarly, though their number is conversely 150 increasing with depth, and all sampled species within the last (the deepest) depth range will 151 represent the lower limits. As an example, imagine if it was a total of 1000 species within the 152 $3000 \mathrm{~m}$ depth range divided into $200-\mathrm{m}$ intervals with $\sim 200$ species occurring in each of the 153 intervals. The examples of expected upper and lower limits of distribution calculated using these values are shown in Fig. 2. Direct calculations behind the examples are available in 155 Supplementary 2.

156 The expected number of upper and lower limits of species distribution was then 157 summarized (Fig. 2). The difference between the observed and expected number of limits was 
158 assessed using the Chi-square test. Differences were considered reliable if the Chi-square results 159 were $>3.84$ (degree of freedom $=1 ; p$-value $=0.05$ ) where the observed number of limits 160 overreached the expected number of limits (Franke et al., 2012).

161 For the details of the described method see Backus et al. (1965), Gage et al. (1984), Gage 162 (1986) and Bamber \& Thurston (1995).

163 The vertical distribution of benthic stations taken between the years 1881 and 2015 was 164 analysed to avoid the bias related to uneven distribution of stations (and samples) within the 165 study area. A set of 1046 stations was tested; the complete list with expedition data and 166 coordinates is shown in Supplementary 3. Spearman ranked correlations were calculated between 167 the stations and species distribution along different depth ranges.

168 Results were plotted as simple graphs, using the Microsoft Office software. Maps were 169 built using the Ocean Data View 5.3.0 software (Schlitzer, 2020). 


\section{Results}

\section{Annelida distribution}

173 Most of the Annelida species occurred within the upper hundreds of meters. Reliable 174 concentrations of the upper and lower range limits were found within the depth ranges of 450$175600 \mathrm{~m}$ (mean Chi sq. value - 38.7) and 700-750 m (mean Chi sq. value - 31.5). Those zones of 176 crowding were revealed applying $50 \mathrm{~m}$ increments in the upper $800 \mathrm{~m}$ (Fig. 3a).

177 Along the entire depth range, zones of crowding of vertical limits occurred at 1000-1200 m 178 (16 limits, Chi sq. value - 9.9), 1800-2000 m (5 limits, Chi sq. value - 5.0) and 2200-2400 m (5 179 limits, Chi sq. value - 6.9) (Fig. 3b).

180

181

182 183 184 185 186 187 188

\section{Crustacea distribution}

Different taxa of Crustacea are characterized by different migration and evolutionary history and show unequal diversity along the depth gradient in the Arctic Ocean (Gurjanova, 1951; Brandt et al., 1996; Brandt, 1997). Therefore, the following Crustacea taxa were analysed separately: Cirripedia, Decapoda, Cumacea, Mysida, Tanaidacea, Isopoda and Amphipoda.

In the first five taxa no significant zones of crowding of the upper and lower vertical limits were found. The species number within each taxon was too small to build a reliable plot (Table $1)$.

In Isopoda significant concentrations of the upper and lower vertical limits were revealed at depth layers 500-700 m and 1200-1400 m (Chi sq. values 18.2 and 16.8, respectively) (Fig. 4). Peaks at 500-700 m were mostly related to the upper vertical limits (11 out of 17 in total), whereas peaks at 1200-1400 m corresponded to the lower vertical limits (10 out of 11 in total).

In Amphipoda concentrations of vertical limits appeared at 450-550 m (mean Chi sq. value - 4.4), 650-700 m (Chi sq. value - 4.1) and 1800-2000 m (Chi sq. value - 6.2). Statistically unreliable small peak was observed at 1000-1200 m depth (Chi sq. value <3.8) (Fig. 5).

Unlike in Isopoda, most of these zones of crowding corresponded to the lower limits of species vertical ranges.

\section{Echinodermata distribution}

In Echinodermata, similar to Annelida and Crustacea, statistically reliable peaks of of vertical limits concentration were revealed at 450-600 m depth (Chi sq. value - 4.3). Additional 
202 zone of crowding occurred at 2200-2400 m (Chi sq. value - 6.5) and two unreliable 203 concentrations were observed at 1000-1200 $\mathrm{m}$ and 1800-2000 m (Chi sq. values <3.8) (Fig. 6).

204 These peaks, like in Amphipoda and Annelida, mainly corresponded to the lower vertical 205 limits - 10 out of 11 in total at 450-600 m; 6 out of 6 at 1000-1200 m; 3 out of 3 at 1800-2000 206 and 4 out of 4 at $2200-2400 \mathrm{~m}$.

207

208

209

210

211

212

213

214

215

216

217

218

219

220

221

222

223

224

225

226

227

228

229

230

231

232

\section{Station distribution}

Analysed stations were distributed unevenly along the depth. Most of the stations were taken on the shelf within the upper $100 \mathrm{~m}$ (389 out of 1046 stations). Deeper $200 \mathrm{~m}$, the number of stations per each 200-m interval was relatively small (Fig. 7).

The distribution of stations along the depth in general correlated with most of observed patterns of taxa vertical distribution. One exception was the vertical distribution of Amphipoda and Echinodermata calculated per 200-m depth intervals (Table 2). However, despite the overall correlation, certain peaks of vertical limits in Annelida, Crustacea and Echinodermata did not correspond to the peaks in the distribution of stations, for example at $600-750 \mathrm{~m}$ in Isopoda and Amphipoda, at $1200-1400 \mathrm{~m}$ in Isopoda and at $1800-2000 \mathrm{~m}$ in Annelida, Amphipoda and Echinodermata.

\section{Revealing the bathymetric boundaries}

Combined data for Annelida, Crustacea and Echinodermata demonstrated several distinct zones of crowding of the upper and lower species vertical limits (Fig. 8). Peaks occurred in all taxa at the following depths: $450-600 \mathrm{~m}, 650-700 \mathrm{~m}$ (Fig. 8a), 1000-1200 m, 1800-2000 m and 2200-2400 m (Fig. 8b). Annelida and Amphipoda, as more species rich, contributed more significantly to this pattern.

The boundary at 1000-1400 m was clearly pronounced only in annelids and isopods, however, it was also visible in amphipods and echinoderms. At greater depths, the clearest concentrations of vertical limits occurred at 1800-2000 $\mathrm{m}$ in annelids and amphipods and less pronounced at 2200-2400 m. At this depth the lower vertical limits of several bathyal species occurres, such as the ophiuroid Ophiopleura borealis and the asteroids Bathybiaster vexillifer and Pontaster tenuispinus (Supplementary 1). 


\section{Discussion}

234 A number of schemes of vertical zonation based on the distribution of benthic fauna in various

235 Arctic regions was suggested earlier (Mironov, 2013). These schemes are barely comparable 236 owing to the difference in methods and approaches used. The number of biogeographic regions 237 or vertical zones increases from schemes based purely on the biotic approach (species - based) to 238 those based on mixed elements of the biotic and biocenotic (communities - based) approaches, 239 and increases further in schemes based on the mixed biocenotic-landscape approaches (Mironov, 240 2013). Below we consider only the schemes of vertical zonation based on the biotic approach 241 (Zhirkov \& Mironov, 1985; Mironov, 1986; Gage, 1986; Svavarsson, 1990; Howell et al., 2002; 242 Oug et al., 2017) (Fig. 9).

243 The true biotic approach to reveal vertical zones in the Arctic Ocean basin has been applied 244 only in the Norwegian Sea (Zhirkov \& Mironov, 1985; Krayushkina, 2000). Additionally the 245 distribution and diversity patterns of the asellote isopods in the deep Norwegian and Greenland 246 Seas were studied by Svavarsson et al. (1990). The authors used the cumulative number of first 247 occurrences of species, the approach similar to the biotic one. Oug et al. (2017) examined 248 changes with depth of the species richness of annelids in the deep Nordic Seas at the alpha 249 (sample species richness), beta (turnover) and gamma (large area species richness) scales. 250 Menzies et al. (1973) studied the vertical distribution of assellote isopods in the high Arctic. The 251 authors suggested a simple method of determining the faunal homogeneity or distinctiveness 252 between depth intervals: the total taxa in common (Tc) between adjacent depth intervals was 253 subtracted from the total taxa $(\mathrm{T})$ at the two depth intervals, divided by the total $(\mathrm{T})$ and 254 multiplied by 100 to gain the percentage of distinctiveness (D): $\mathrm{T}-\mathrm{Tc} / \mathrm{T} \times 100=$ 255 distinctiveness D.

256 The boundary at 450-800 $\mathrm{m}$ revealed in our study for the first time roughly corresponds to 257 boundaries shown in Krayushkina (2000) and Oug et al. (2017) (Fig. 8) and is close to the 258 boundary at $425 \mathrm{~m}$ in Menzies et al. (1973). The boundary at 1200-1400 $\mathrm{m}$ (for Isopoda in our 259 study) also can be found in Krayushkina (2000), whereas the boundary at 1800-2000 $\mathrm{m}$ is close 260 to the boundary in the scheme of Oug et al. (2017). Our results do not correlate with the schemes 261 of Jirkov \& Mironov (1985) and Svavarsson et al. (1990) (Fig. 9), however in the later scheme 262 there is a boundary at $2000 \mathrm{~m}$ revealed using different methods (cluster analysis - the biocenotic 263 approach). 
We suggest that the depth interval $450-800 \mathrm{~m}$ in our study represents the boundary 265 between the sublittoral and bathyal faunas since it was the shallowest reliable boundary we 266 found. Such biogeographic boundaries are associated with sharp breaks in gradients of

267 268 269

270

271

272

273

274 275

276

277

278

279

280

281

282

283

284

285

286

287

288

289

290

291

292

293

294 environmental parameters (Rapoport, 1982; Mironov, 2004; Mironov et al., 2013; Watling, 2013). In case of the sublittoral zone, its lower boundary is usually associated with pronounced changes in the deposition and burial of the organic matter at the seafloor. The lower boundary of the faunistic sublittoral zone roughly corresponds to the lower boundary of the photic zone and the depth of the continental shelf break in the Ocean at 200 m (Ekman, 1953; Carney et al., 1983; Mironov, 1986; Carney, 2005; Wei et al., 2010). In particular, the exact depth of this boundary was reported at 200-300 m off the North-East coast of the USA (Haedrich et al., 1980; Rowe et al., 1982); at 150-200 $\mathrm{m}$ in the North-East Atlantic (Mironov, 1986). Overall, the lower sublittoral boundary is usually drawn at depths shallower 400 m (Hedgpeth, 1957; Belyaev et al., 1959; Vinogradova, 1962; Haedrich et al., 1980; Gage \& Tyler, 1992; Thistle, 2003; Watling et al., 2013).

However, in the Arctic seas conditions for photosynthesis are different from the lower latitudes since they are constrained by the ice cover and the lighting regime (Boetius et al., 2013; Flint et al., 2019). By generalised characteristics of photosynthesis, the shelf of the Siberian seas resembles the so called «mesophotic ecosystems». Such ecosystems are characterized by lowlight conditions (Hinderstein et al., 2010; Easton et al., 2019; Pyle \& Copus, 2019; Mecho et al., 2021). Apparently the break in the photosyntetic gradient in the Siberian seas at depths about 200 $\mathrm{m}$ is weakly pronounced. If so, it can be suggested that the biotic boundary has not developed there owing to the lack of sharp changes at this depth in the deposition of organic matter of photosynthetic origin to the seafloor in the Siberian seas.

The revealed in this study deeper sublittoral boundary at 450-800 m apparently indicates significant changes in trophic conditions at this depth. However, specific environmental factors controlling the inflow of organic matter at this depth are not obvious, further studies are required. The "deep" lower sublittoral boundary is also a feature of the Antarctic (Fig. 9, Mironov, 1986). It was suggested that this effect in the Antarctic is related to the peculiar geomorphology with the continental shelf sunken as a result of the glaciers pressure (Brey et al., 1996; Tatje et al., 2005; Martín-Ledo \& López-González, 2014). During the series of the Pleistocene glaciations, the ice sheet was bending the Antarctic crust forcing many shallow-water species to migrate deeper and 
295 adapt to eurybathy (Brey et al., 1996; Tatje et al., 2005). However, this is not the case for the 296 Arctic Ocean, since the history of the Arctic fauna is completely different. Within the study area, 297 possible reasons for the described boundary can be associated with peculiar geomorphology of 298 the shelf-slope area and the hydrological regime. The Siberian shelf is one of the widest in the 299 world, up to $800 \mathrm{~km}$ (Weber, 1989). In addition, it is characterized by a strong fresh water 300 outflow (Flint et al., 2019). As an example, the annual freshwater discharge from all major 301 Arctic rivers is approximately $3300 \mathrm{~km}^{3}$, equivalent to $10 \%$ of the global river-off. Just two 302 rivers, the $\mathrm{Ob}$ and Yenisei, discharge about 30\% of the total annual river run-off into the Arctic 303 Ocean through the Kara Sea (Fütterer \& Galimov, 2003; Stein, 2000). From the ocean side, the 304 upper slope of the Siberian seas is bathed by the warm Atlantic waters (Aagard, 1989; Rudels et 305 al., 1994; Bluhm et al., 2020), the factor that potentially can influence trophic conditions by 306 enriching the upper slope with organic carbon (Dunton, 1992; Wassman et al., 2019; Bluhm et al., 2020). The lower boundary of the Atlantic layer in the Siberian Arctic represents a rather sharp 308 gradient from 2-3 ${ }^{\circ} \mathrm{C}$ and $\sim 35 \mathrm{psu}$ to $\sim-1{ }^{\circ} \mathrm{C}$ and $\sim 32-33$ psu at depths of 500-700 $\mathrm{m}$ (Bluhm et al., 2020). Faunal changes coinciding with the inflow of Atlantic waters were reported for annelids, isopods, gastropods and fishes in the Norwegian Sea, where the gradient is particularly high (Svavarsson et al., 1990; Bergstad et al., 1999; Høisæter, 2010; Oug et al., 2017).

The boundary between the bathyal and abyssal faunas revealed in our study for the first time at the depth of 1800-2000 m lies, on the contrary, shallower than in many other ocean regions ( 3000 m) (Gebruk, 2010). The bathyal-abyssal fauna boundary is considered by some authors as related to the decrease in food availability with depth, certain changes in temperature regime (such as the $4^{0} \mathrm{C}$ isotherm) and the near-bottom currents associated with changes in the 317 bottom topography at the transition from the continental slope to the continental rise and abyssal plain at 2400-3600 m (Menzies et al., 1973; Gage, 1986; Gage \& Tyler, 1992; Thistle, 2003; Wei et al., 2010; Watling et al., 2013). The decrease in the food availability with depth demonstrated rapid drops in benthic production approximately within the continental rise area in the Central Arctic (Degen et al., 2015). Important feature of the continental rise is that it represents the site of accumulation of most of the detrital sediment eroded off the continents (Hay, 2016). Sokolova (2000) presented evidence that at the transition from the continental rise to the continental slope in the Ocean (at $\sim 3000 \mathrm{~m}$ depth) the organic carbon content in the sediment is higher. This is a result of accumulation of organic matter buried in the sediment sliding down the slope (Hay, 
326 2016). This zone contours all continents and it was marked by Sokolova (2000) as the

327 "Circumcontinental eutrophic zone". In the Arctic Ocean the decrease of the slope inclination at 328 the transition from the continental shelf to the continental rise was shown for some areas north of 329 the Kara, Laptev and East-Siberian seas at 2000 m (Jakobsson et al., 2020; Bluhm et al., 2020). 330 This is shallower than in the scheme of Sokolova (2000) and this is apparently a regional 331 peculiarity of the basin. Certain changes in benthic communities were revealed using the

332 biocenotic approach in some areas of the Laptev and East-Siberian seas at $\sim 1900-2000 \mathrm{~m}$ 333 (Sirenko et al., 2004) and 1740-2100 m (Deubel, 2000). There are reasons to believe that these 334 changes and the boundary identified in the present study at 1800-2000 $\mathrm{m}$ are related to the 335 bottom topography and first of all to the transition from the continental rise to the continental 336 slope at this depth.

337 Whatever the case, the bathymetric distribution of benthic fauna in the Arctic Ocean has 338 unique features not found in other Ocean regions. The generalized scheme of vertical zonation of 339 the Arctic benthic fauna based on the analysis of species range limits is shown in Fig. 10.

341 Conclusions

342 The boundaries between the sublittoral, bathyal and abyssal faunas exist in the Arctic, but they 343 lie at depths uncommon for other Ocean areas. Reported in the present study the zone of 344 crowding (concentration) of the upper and lower species vertical limits at 450-800 m likely 345 marks the boundary between the sublittoral and bathyal faunas. Commonly in the Ocean this 346 boundary occurs at 150-250 m depth (except for the Antarctic). It remains unclear why in the 347 Siberian seas the lower boundary of the sublittoral zone lies deeper than elsewhere in the Ocean. 348 The boundary between the bathyal and abyssal faunas was observed at 1800-2000 m, which is, 349 on the contrary, shallower, than in other Ocean regions (for example 2400-3600 m in the North 350 Atlantic and North Pacific). It can be suggested that this boundary at least in part is a result of the 351 transition from the continental slope to the continental rise at shallower depths $(\sim 2000 \mathrm{~m})$ in the 352 Siberian Arctic.

353

354

\section{Acknowledgements}

355 The authors are thankful to Dr. Natalya Budaeva, Dr. Kirill Minin, Dr. Alexey Udalov, Dr. 356 Vassily Spiridonov and Dr. Victor Petryashev for their help with literature search. Many thanks 357 are due to Dr. Antje Boetius and Dr. Ingrid Krönke for providing original macrobenthic samples 358 from earlier expeditions. 


\section{References}

360

361

362

363

364

365

366

367

368

369

370

371

372

373

374

375

376

377

378

379

380

381

382

383

384

385

386

387

388

389

390

391

392

393

394

395

396

397

398

399

400

401

402

403

404

405

406

407

408

1. Aagaard, K. (1989). A synthesis of the Arctic Ocean circulation. Rapp. P.-V. Reun. Cons. Int. Explor. Mer. 188, 11-22.

2. Anisimova, N.A. (1989). Distribution patterns of echinoderms in the Eurasian sector of the Arctic Ocean. In: Herman Y. (ed.) The Arctic Seas. Clymatology, Oceanography, Geology, and Biology. New York: Van Nostrand Reinhold Company, pp. 281-301.

3. Anisimova, N.V., Frolova, E.A., Lubin, P.A., Frolova, A.A., Denisenko, N.V., Panteleeva, N.N., Lubina, O.S. (2003). Species composition and quantitative distribution of macrobenthos in the Voronintrench and on the adjacent continental slope. Fauna of invertebrates of Kara, Barents and White Seas (ecology, biogeography). 79-92.

4. Antipova T.V., Semenov V.N. (1989). Benthos of the Kara Sea. Benthos biocenoses in the southwestern areas of the Kara Sea. In: Matishov G.G., Petrov V.S., Chinarina A.D., Pavlova L.G., Timofeev S.F. (eds) Ecology and bio-resources of the Kara Sea. KSC RAS, Apatity, pp 120-127. [In Russian]

5. Backus, R. H., Mead, G. W., Headrich, R. L., Ebeling, A. W. (1965). The mesopelagic fishes collected during Cruise 17 of the $\mathrm{R} / \mathrm{V}$ Chain with a method for analyzing faunal transects. Bulletin of the Museum of Comparative Zoology, 134 (5): 139-157.

6. Bamber R.N., Thurston M.H. (1995). The deep-water pycnogonids (Arthropoda: Pycnogonida) of the northeastern Atlantic Ocean. Zoological journal of the Linnean Society, 115(2), 117-162.

7. Belyaev G.M., Birstein J.A., Bogorov V.G., Vinogradova N.G., Vinogradov M.E., Zenkevitch L.A. (1959). A diagram of the vertical biological zonality of the ocean. Doklady Akademii Nauk SSSR, 129, 658-661. [In Russian]

8. Bergstad, O. A., Bjelland, O., Gordon, J. D. (1999). Fish communities on the slope of the eastern Norwegian Sea. Sarsia, 84(1), 67-78.

9. Bluhm, B. A., Janout, M.A., Danielson, S.L., Ellingsen, I., Gavrilo, M., Grebmeier, J., Hopcroft, R.R., Iken, K., Ingvaldsen, R., Jørgensen, L.L., Kosobokova, K., Kwok, R., Polyakov, I., Renaud, P., Carmack, E. (2020). The pan-Arctic continental slope: sharp gradients of physical processes affect pelagic and benthic ecosystems. Frontiers in Marine Science.doi: 10.3389/fmars.2020.544386

10. Boetius, A., Albrecht, S., Bakker, K., Bienhold, C., Felden, J., Fernández-Méndez, M., ...\& ARK27, Bakker, K., Bienhold, C., Felden, J., Fernández-Méndez, M., Hendricks, S., Katlein, C., Lalande, C., Krumpen, T., Nicolaus, M., Peeken, I., Rabe1, B., Rogacheva, A., Rybakova, E., Somavilla, R., Wenzhöfer, F., RV Polarstern ARK27-3-Shipboard Science Party, (2013). Export of algal biomass from the melting Arctic sea ice. Science, 339(6126), 1430-1432.

11. Brandt A., Vassilenko S., Piepenburg D., Thurston M. (1996). The species composition of the peracarid fauna (Crustacea, Malacostraca) of the Northeast Water Polynya (Greenland). Meddelelser om Grønland, Bioscience, Vol. 44: 1-30.

12. Brandt A. (1997). Biodiversity of peracarid crustaceans (Malacostraca) from the shelf down to the deep Arctic Ocean. Biodiversity and Conservation, 6: 1533-1556.

13. Brey, T., Dahm, C., Gorny, M., Klages, M., Stiller, M., Arntz, W. (1996). Do Antarctic benthic invertebrates show an extended level of eurybathy? Antarctic Science, 8, 3-6.

14. Carney, R. S., Haedrich, R. L. Rowe, G. T. (1983). Zonation of fauna in the deep sea. In: Rowe, G.T. (Ed.) The Sea. Vol. 8: Deep-sea biology, 97-122.

15. Carney, R. S. (2005). Zonation of deep biota on continental margins. In: (Gibson, R.N., Atkinson, R.J.A., Gordon, J.D.M. (Eds.) Oceanography and Marine Biology: an annual review, 43, p. 211-278.

16. Deacon, G. E. R. (1982). Physical and biological zonation in the Southern Ocean. Deep Sea Research Part A. Oceanographic Research Papers, 29(1), 1-15.

17. Degen, R., Vedenin, A., Gusky, M., Boetius, A., Brey, T. (2015). Patterns and trends of macrobenthic abundance, biomass and production in the deep Arctic Ocean. Polar Research, 34(1), 24008.

18. Deubel, H. (2000). Struktureigenschaften und Nahrungsbedarf der Zoobenthosgemeinschaftenim Bereich des Lomonossowrückensim Arktischen Ozean. Berichte zur Polarforschung, 370.

Peer) reviewing PDF | (2021:03:58651:2:0:NEW 19 May 2021) 
409

410

411

412

413

414

415

416

417

418

419

420

421

422

423

424

425

426

427

428

429

430

431

432

433

434

435

436

437

438

439

440

441

442

443

444

445

446

447

448

449

450

451

452

453

454

455

456

457

458

459

19. Deubel H., Engel M., Fetzer I., Gagaev S., Hirche H.J., Klages M., Larionov V., Lubin P., Lubina O., Nothig E.M., Okolodkov Y., Rachor E. (2003) The southern Kara Sea ecosystem: Phytoplankton, zooplankton and benthos communities influenced by river run-off. In: Ruediger S. (ed) Siberian River Runoff in the Kara Sea: characterization, quantification variability and environmental significance. Proceedings in Marine Science, 6, Elsevier, Amsterdam, pp 237-275.

20. Dunton, K. (1992). Arctic biogeography: the paradox of the marine benthic fauna and flora. Trends in Ecology \& Evolution, 7(6), 183-189.

21. Easton, E. E., Gorny, M., Mecho, A., Sellanes, J., Gaymer, C., Spalding, H. L., Aburto, J. (2019). Chile and Salas the y Gómez Ridge. In: Loya, Y., Puglise, K. A., Bridge, T. C. L. (Eds) Mesophotic coral ecosystems. Springer, New York, pp. 477-490.

22. Ekman, S. (1953). Zoogeography of the Sea. London: Didgewick and Jackson.

23. Filatova Z.A., Zenkevich L.A. (1957). The quantitative distribution of the bottom fauna of the Kara Sea. Trydy Vsesoyuznogo Gidrobiologicheskogo Obshchestva 8:3-67. [In Russian]

24. Flint, M. V., Poyarkov, S. G., Rimskii-Korsakov, N. A., Miroshnikov, A. Y. (2019). Ecosystems of the Siberian Arctic Seas 2018 (Cruise 72 of the R/V Akademik Mstislav Keldysh). Oceanology, 59(3), 460-463.

25. Franke, T. M., Ho, T., Christie, C. A. (2012). The chi-square test: Often used and more often misinterpreted. American Journal of Evaluation, 33(3), 448-458.

26. Fütterer , D. K. (1994). The Expedition ARCTIC '93 Leg ARK-IX/4 of RV "Polarstern" 1993. Reports on Polar Research. Vol. 149.Fütterer, D. K., Galimov E.M. (2003). Siberian rover run-off in the Kara Sea: Characterisation, quantification, variability and environmental significance - An introduction. Proceeding in Marine Science. In: Stein R., Fahl K., Fütterer D.K., Galimov E.M., Stepanents O.V. (Eds.) Siberian rover run-off in the Kara Sea. Characterisation, quantification, variability and environmental significance. Elsevier: Amsterdam, V. 6, pp. 1-8.

27. Gage, J.D., Pearson, M., Billett, D.S.M., Clark, A.M., Jensen, M., Paterson, G.L.J., Tyler, P.A. (1984). Echinoderm zonation in the Rockall Trough (NE Atlantic). Proceedings of the Fifth International Echinoderm Conference, Galway, Echinodermata, 31-36.

28. Gage J. (1986). The benthic fauna of the Rockall Trough: regional distribution and Bathymetric zonation. Proceedings of Royal Society of Edinburgh, 88b: 159-174.

29. Gage J. D., Tyler P. A. (1992). Deep-sea biology: a natural history of organisms at the deep-sea floor. Cambridge University Press. 504 p.

30. Galkin, S. V., Vedenin, A. A. (2015). Macrobenthos of Yenisei Bay and the adjacent Kara Sea shelf. Oceanology, 55(4), 606-613.

31. Gardiner, F. P., Haedrich, R. L. (1978). Zonation in the deep benthic megafauna. Oecologia, 31(3), 311-317.

32. Gebruk, A. V., Budaeva, N. E., King, N. J. (2010). Bathyal benthic fauna of the Mid-Atlantic Ridge between the Azores and the Reykjanes Ridge. Marine Biological Association of the United Kingdom. Journal of the Marine Biological Association of the United Kingdom, 90(1), 1-14.

33. Golikov, A.N. (1989). Arctic Ocean gastropod prosobranchs. In: Herman Y. (ed.) The Arctic Seas. Clymatology, Oceanography, Geology, and Biology. New York: Van Nostrand Reinhold Company, pp. 325-340.

34. Golikov, A. N., Dolgolenko, M. A., Maximovich, N. V., Scarlato, O. A. (1990). Theoretical approaches to marine biogeography. Marine ecology progress series. Oldendorf, 63(2), 289-301.

35. Grassle, J. F., \& Morse-Porteous, L. S. (1987). Macrofaunal colonization of disturbed deep-sea environments and the structure of deep-sea benthic communities. Deep Sea Research Part A. Oceanographic Research Papers, 34(12), 1911-1950.

36. Gukov, A.Y. (1999). Ecosystems of the Siberian Polynya. Nauchnyy Mir, Moscow. 334 p. [In Russian]

37. Gukov, A. Y., Dudarev, O. V., Semiletov, I. P., Charkin, A. N., Gorshkova, Y. S. (2005). Distribution of macrobenthos biomass and bottom biocoenoses in the southern East Siberian Sea. Oecanology, $45(6), 841$.

Peer] reviewing PDF | (2021:03:58651:2:0:NEW 19 May 2021) 
460 461 462 463 464 465 466 467 468 469 470 471 472 473 474 475 476 477 478 479

480

481

482

483

484

485

486

487

488

489

490

491

492

493

494

495

496

497

498

499

500

501

502

503

504

505

506

507

508

509
38. Gurjanova E.F. (1951). Amphipods of the seas of USSR and adjacent waters (Amphipoda, Gammaridea). IzdadelstvoAkademiiNauk SSSR, Moscow-Leningrad. 1031 p. [In Russian]

39. Hay, W. W. (2016). Continental slope. Encyclopedia of marine geosciences. Springer, Berlin. https://doi.org/10.1007/978-94-007-6644-0 156-3.

40. Haedrich, R.L., Rowe, G.T., Polloni, P.T. (1980). The megabenthic fauna in the deep sea south of New England, USA. Marine Biology, 57 (3): 165-179.

41. Hedgpeth, J.W. (1957). Classification of marine environments. Geological Society of America Memoir, 67 (1): 17-27.

42. Hinderstein, L. M., Marr, J. C. A., Martinez, F. A., Dowgiallo, M. J., Puglise, K. A., Pyle, R. L., Zawada, D. G., Appeldoorn, R. (2010). Theme section on "Mesophotic coral ecosystems: characterization, ecology, and management". Corel Reefs, 29(2), 247-251.

43. Høisæter, T. (2010). The shell-bearing, benthic gastropods on the southern part of the continental slope off Norway. Journal of Molluscan Studies, 76(3), 234-244.

44. Howell K. L., Billett D. S. M., Tyler P. A. (2002). Depth-related distribution and abundance of seastars (Echinodermata: Asteroidea) in the Porcupine Seabight and Porcupine Abyssal Plain, N.E. Atlantic. Deep-Sea Research. Part I, 49: 1901-1920.

45. Jakobsson, M., Mayer, L.A., Bringensparr, C., Castro, C.F., Mohammad, R., Johnson, P., Ketter, T., Accettella, D., Amblas, D., An, L., Arndt, J.E., Canals, M., Casamor, J.L., Chauché, N., Coakley, B., Danielson, S., Demarte, M., Dickson, M.-L., Dorschel , B., Dowdeswell, J.A., Dreutter, S., Fremand, A.C., Gallant, D., Hall, J.K., Hehemann, L., Hodnesdal, H., Hong, J., Ivaldi, R., Kane, E., Klaucke, I., Krawczyk, D.W., Kristofersen, J., Kuipers, B., Millan, R., Masetti, G., Morlighem , M., Noormets , R., Prescott, M.M., Rebesco, M., Rignot, E., Semiletov, I., Tate, A.J., Travaglini, P., Velicogna, I., Weatherall, P., Weinrebe, W., Willis, J.K., Wood, M., Zarayskaya, Y., Zhang, T., Zimmermann, M., Zinglersen, K.B. (2020). The International Bathymetric Chart of the Arctic Ocean Version 4.0. Sci Data 7, 176. https://doi.org/10.1038/s41597-020-0520-9

46. Jamieson, A. (2015). The Hadal Zone: Life in the Deepest Oceans. Cambridge University Press.

47. Jørgensen, L. L., Pearson, T. H., Anisimova, N. A., Gulliksen, B., Dahle, S., Denisenko, S. G., Matishov, G. G. (1999). Environmental influences on benthic fauna associations of the Kara Sea (Arctic Russia). Polar Biology, 22(6), 395-416.

48. Krayushkina, A. B. (2000). Geography of the asteroids and holothurians of the Norwegian Sea. Benthos of the Russian Seas and the Northern Atlantic. Moscow: VNIRO Publishing House, 41. [In Russian]

49. Longhurst, A. R. (1985). The structure and evolution of plankton communities. Progress in Oceanography, 15(1), 1-35.

50. Martín-Ledo, R., López-González, P. J. (2014). Brittle stars from Southern Ocean (Echinodermata: Ophiuroidea). Polar biology, 37(1), 73-88.

51. Mecho, A., Dewitte, B., Sellanes, J., van Gennip, S., Easton, E. E., Gusmao, J. B. (2021). Environmental Drivers of Mesophotic Echinoderm Assemblages of the Southeastern Pacific Ocean. Frontiers in Marine Science. https://doi.org/10.3389/fmars.2021.574780

52. Menzies, R. J., George, R. Y. Rowe, G. T. (1973). Abyssal Environment and Ecology of the World Oceans. New York: John Wiley.

53. Milkov, F. N. (1970). Landscape sphere of the Earth. Mysl', Moscow, USSR. 207 p. [In Russian]

54. Mironov, A. N. (1986). Vertical zonation of the sea urchins. Zoological Journal, 65(9): 1341-1349. [In Russian]

55. Mironov A. N. (2004). Nature of the biotic boundaries. In: Kafanov A. I. (ed.) Main problems in marine biogeography. In memory of the academician O. G. Kussakin. Vladivostok: Dalnauka. pp. 6797. [In Russian]

56. Mironov, A. N. (2013). Biotic complexes of the Arctic Ocean. Invertebrate Zoology, 10(1), 3-48.

57. Mironov, A. N., Dilman, A. B., Krylova, E. M. (2013). Global distribution patterns of genera occurring in the Arctic Ocean deeper 2000 m. Invertebrate Zool, 10(1), 167-194.

Peer) reviewing PDF | (2021:03:58651:2:0:NEW 19 May 2021) 
510

511

512

513

514

515

516

517

518

519

520

521

522

523

524

525

526

527

528

529

530

531

532

533

534

535

536

537

538

539

540

541

542

543

544

545

546

547

548

549

550

551

552

553

554

555

556

557

558

559

58. Oug, E., Bakken, T., Kongsrud, J. A., Alvestad, T. (2017). Polychaetous annelids in the deep Nordic Seas: Strong bathymetric gradients, low diversity and underdeveloped taxonomy. Deep Sea Research Part II: Topical Studies in Oceanography, 137, 102-112.

59. Pyle, R. L., Copus, J. M. (2019). Mesophotic coral ecosystems: introduction and overview. In: Riegl, B. M., Dodge, R. E. (Eds.) Mesophotic coral ecosystems. Springer, Cham, pp. 3-27

60. Rapoport E. H. (1982). Areography. Geographical strategies of species. Oxford: Pergamon Press. 269 p.

61. Rex, M. A., Etter, R. J. (2010). Deep-sea biodiversity: pattern and scale. Harvard University Press.

62. Rudels, B., Jones, E. P., Anderson, L. G., \& Kattner, G. (1994). On the intermediate depth waters of the Arctic Ocean. The polar oceans and their role in shaping the global environment: the Nansen Centennial Volume. Geophysical Monographs, 85, 33-46.

63. Rybakova, E., Kremenetskaia, A., Vedenin, A., Boetius, A., Gebruk, A. (2019). Deep-sea megabenthos communities of the Eurasian Central Arctic are influenced by ice-cover and sea-ice algal falls. PloS one, 14(7), e0211009.

64. Schlitzer, R. (2020). Ocean Data View. https://odv.awi.de/.

65. Sirenko, B., Denisenko, S., Deubel, H., Rachor, E. (2004). Deep water communities of the Laptev Sea and adjacent parts of the Arctic Ocean. Fauna and the ecosystems of the Laptev Sea and adjacent deep waters of the Arctic Ocean. Explorations of the fauna of sea. St. Petersburg: Zoological Institute of Russian Academy of Sciences, 54(62), 28-73.

66. Sirenko, B. I., Denisenko, S. G. (2010). Fauna of the East Siberian Sea, distribution patterns and structure of bottom communities. Explorations of the fauna of the Seas, 66, 74.

67. Smirnov, I.S. (1984). Fauna of ohiuroids of Antarctica and Subantarctica.

68. Sokolova, M.N. (2000). Feeding and trophic structure of the deep-sea macrobenthos. Washington, D.C.: Smithsonian Institution Libraries. 264 p.

69. Stein, R. (2000). Circum Arctic river discharge and its geological records. International Journal of Earth Science, 89: 447-449.

70. Stepanjants S. D. (1989). Hydrozoa of the Eurasian Arctic seas. In: Herman Y. (ed.) The Arctic Seas. Clymatology, Oceanography, Geology, and Biology. New York: Van Nostrand Reinhold Company, pp. 397-430.

71. Svavarsson J., Brattegard T. Strömberg J.-O. (1990). Distribution and diversity pattern of asellote isopods (Crustacea) in the deep Norwegian and Greenland Seas. Progress in Oceanography, 24: 297310.

72. Thatje, S., Hillenbrand, C. D., Larter, R. (2005). On the origin of Antarctic marine benthic community structure. Trends in Ecology \& Evolution, 20(10), 534-540.

73. Thistle, D. (2003). The deep-sea floor: an overview. In: Tyler, P. (ed.) Ecosystems of the deep oceans. Elsevier, Amsterdam, pp. 6-3.7

74. Thurman, H. V. (1985). Introductory oceanography. Columbus, Ohio: Charles E. Merrill Publishing Company, A. Bell \& Howell Company.

75. Vassilenko S. V. (1989). Arctic Ocean Cumacea. In: Herman Y. (ed.). The Arctic Seas. Clymatology, Oceanography, Geology, and Biology. New York: Van Nostrand Reinhold Company, pp. 431-444.

76. Vedenin, A. A., Galkin, S. V., Kozlovskiy, V. V. (2015). Macrobenthos of the Ob Bay and adjacent Kara Sea shelf. Polar Biology, 38(6), 829-844.

77. Vedenin, A., Gusky, M., Gebruk, A., Kremenetskaia, A., Rybakova, E., Boetius, A. (2018). Spatial distribution of benthic macrofauna in the Central Arctic Ocean. PloS one, 13(10), e0200121.

78. Vedenin, A. A., Galkin, S. V., \& Gebruk, A. V. (2021). List of macrobenthic species: Data from the Siberian Seas and the adjacent area of the deep-sea Central Arctic. Data in Brief, 107115.

79. Vinogradova, N.G., (1962). Vertical zonation in the distribution of deep-sea benthic fauna in the ocean. Deep-Sea Research, 8: 245-250.

80. Wassmann, P. F., Slagstad, D., Ellingsen, I. (2019). Advection of mesozooplankton into the northern Svalbard shelf region. Frontiers in Marine Science, 6, 458.

Peer) reviewing PDF | (2021:03:58651:2:0:NEW 19 May 2021) 
560 561

562

563

564

565

566

567

568

569

570
81. Watling, L., Guinotte, J., Clark, M. R., Smith, C. R. (2013). A proposed biogeography of the deep ocean floor. Progress in Oceanography, 111, 91-112.

82. Weber J.R. (1989). Physiography and bathymetry of the Arctic Ocean seafloor. In: Herman Y. (ed.). The Arctic Seas. Clymatology, Oceanography, Geology, and Biology. New York: Van Nostrand Reinhold Company, pp. 797-828.

83. Wei, C. L., Rowe, G. T., Hubbard, G. F., Scheltema, A. H., Wilson, G. D., Petrescu, I., Foster, J. M., Wicksten, M. K., Chen, M., Davenport, R., Soliman, Y., Wang, Y. (2010). Bathymetric zonation of deep-sea macrofauna in relation to export of surface phytoplankton production. Marine Ecology Progress Series, 399, 1-14.

84. Zhirkov I.A., Mironov A.N. (1985). Contribution to zoogeography of arctic Polychaeta. Trudy Instituta Okeanologii AN SSSR, 120: 137-151. [in Russian] 
Figure 1

Fig. 1. Study area with formal borders of the Kara, Laptev and East Siberian seas.

The adjacent sector of the Central Arctic Basin is outlined with dashed lines - the uniformity of fauna of the entire deep-sea Central Arctic is suggested.

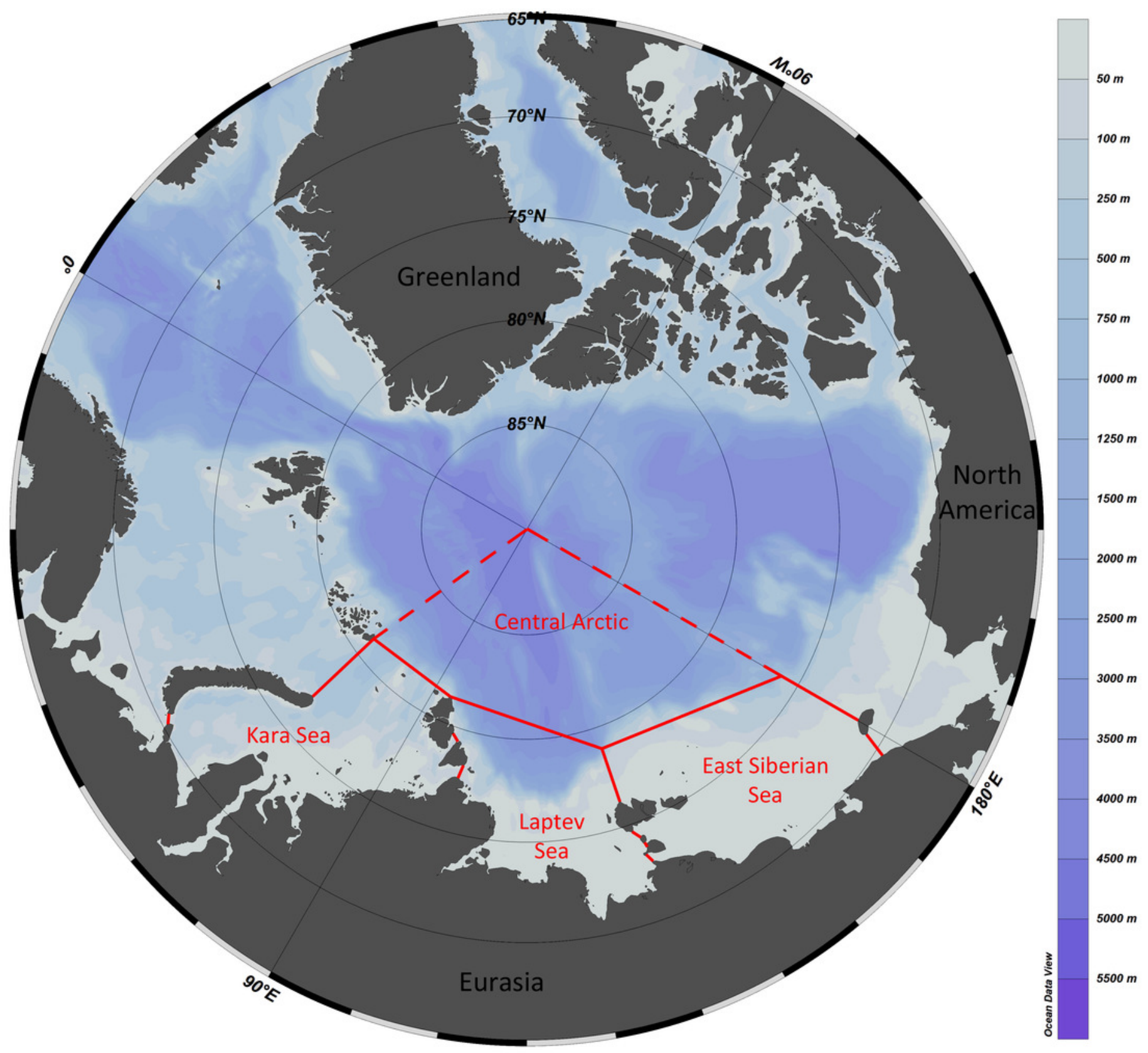


Figure 2

Fig. 2. Example of the plotted expected number of upper and lower vertical limits of species distribution based on Backus equation.

$a(x)$ upper - expected number of the upper vertical limits; $a(x)$ lower - expected number of the lower vertical limits; $a(x)$ upper $+a(x)$ lower - summarized values of upper and lower vertical limits.

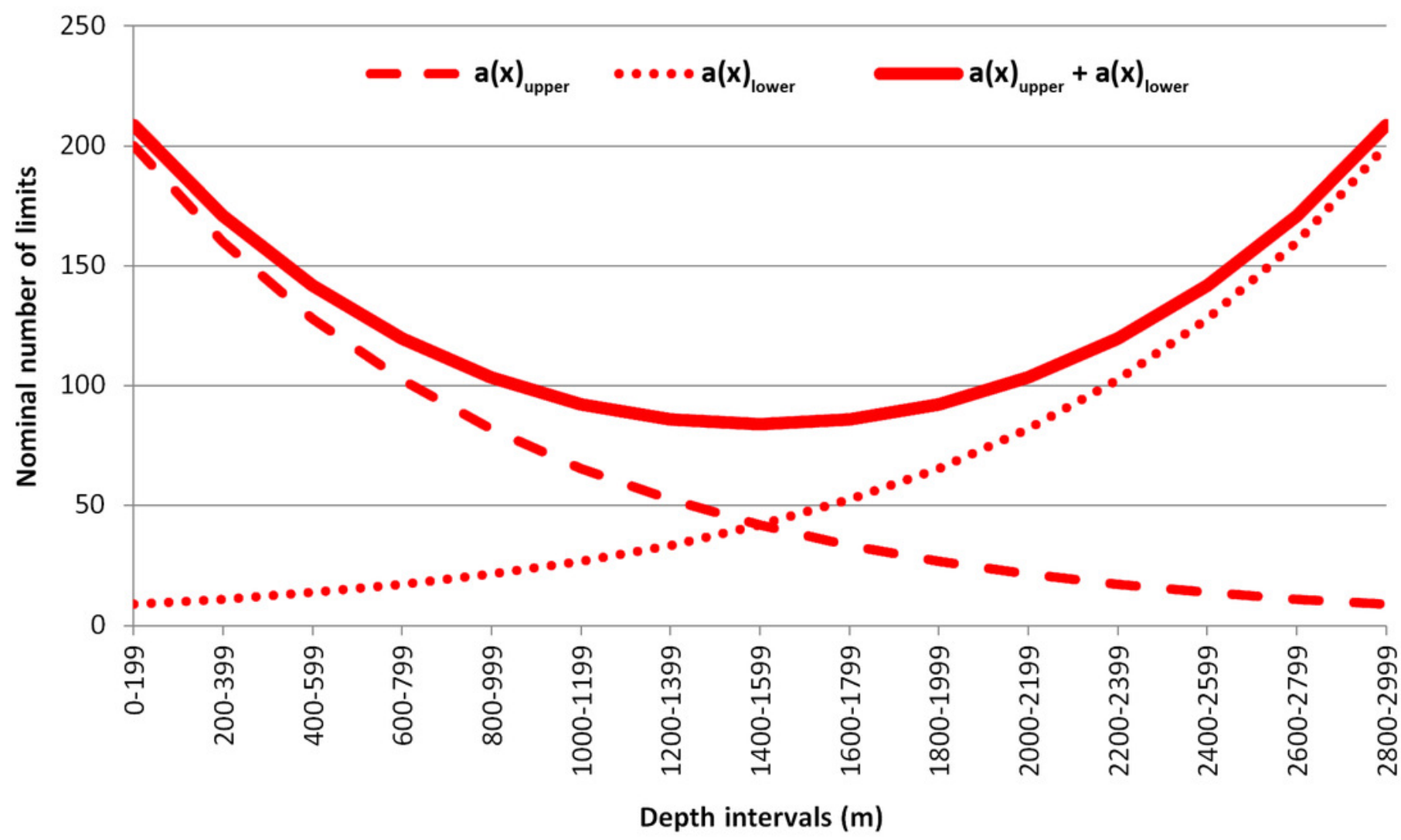


Figure 3

Fig. 3. Distribution of upper and lower vertical limits in species of Annelida.

Observed limits are coloured in blue; expected - in red; grey bars indicate Chi sq. values. A upper $800 \mathrm{~m}$ divided into 50-m intervals; B - entire depth range divided into 200-m intervals.

A

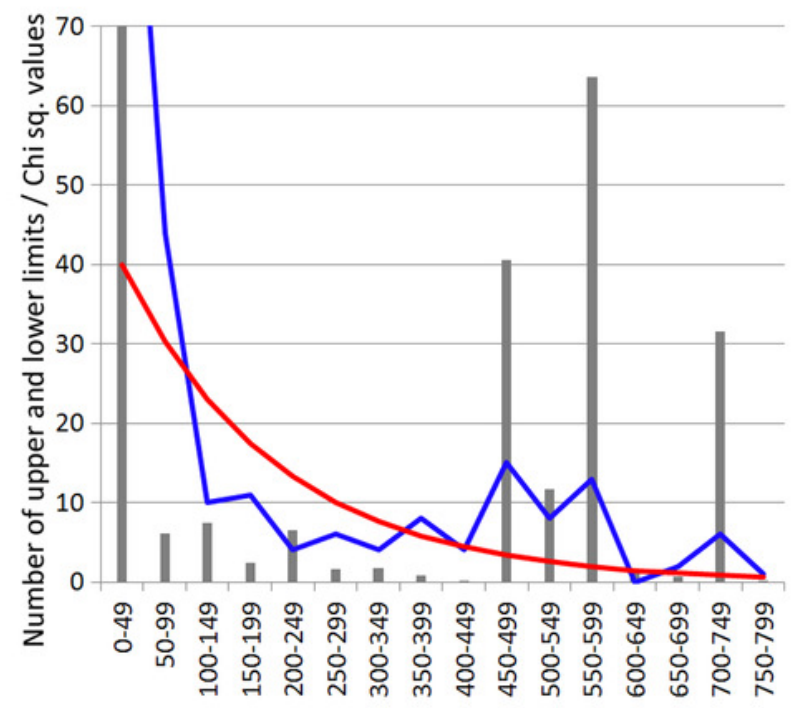

Depth ranges $(\mathrm{m})$
B

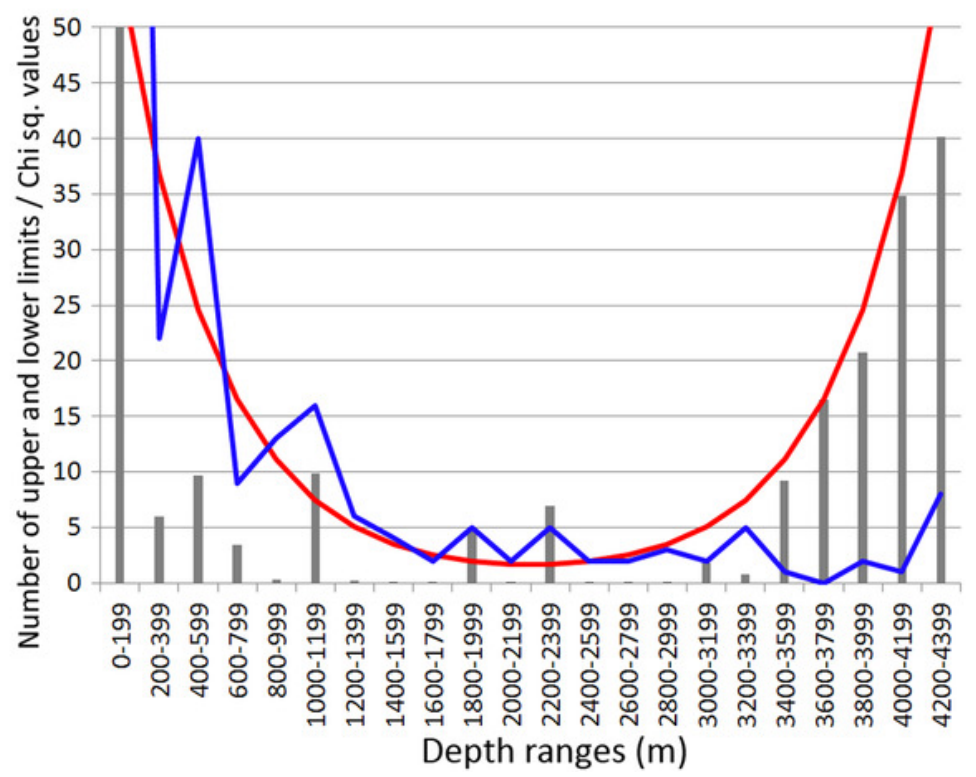


Figure 4

Fig. 4. Distribution of upper and lower vertical limits in species of Isopoda.

Observed limits are coloured in blue; expected - in red; grey bars indicate Chi sq. values. A upper $800 \mathrm{~m}$ divided into 50-m intervals; B - entire depth range, divided into 200-m intervals.

A

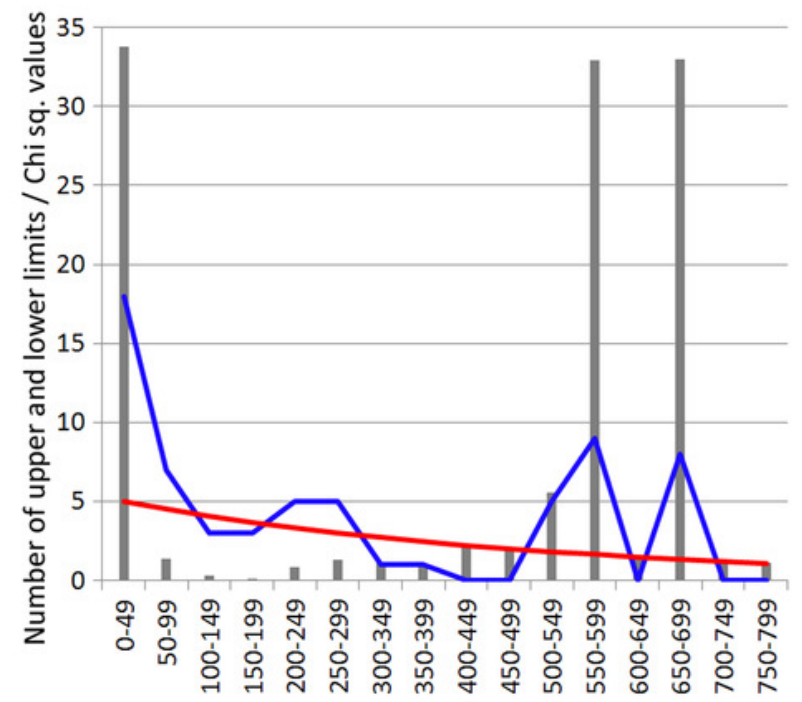

Depth ranges $(\mathrm{m})$
B

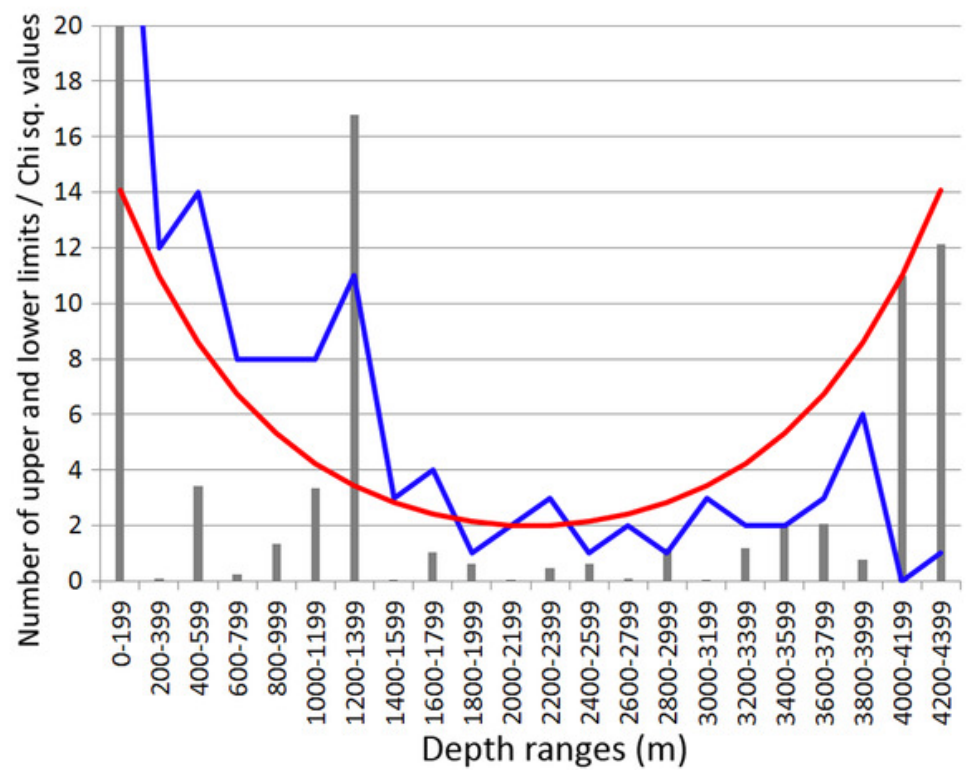


Figure 5

Fig. 5. Distribution of upper and lower vertical limits in species of Amphipoda.

Observed limits are coloured in blue; expected - in red; grey bars indicate Chi sq. values. A upper $800 \mathrm{~m}$ divided into 50-m intervals; B - entire depth range, divided into 200-m intervals.

A

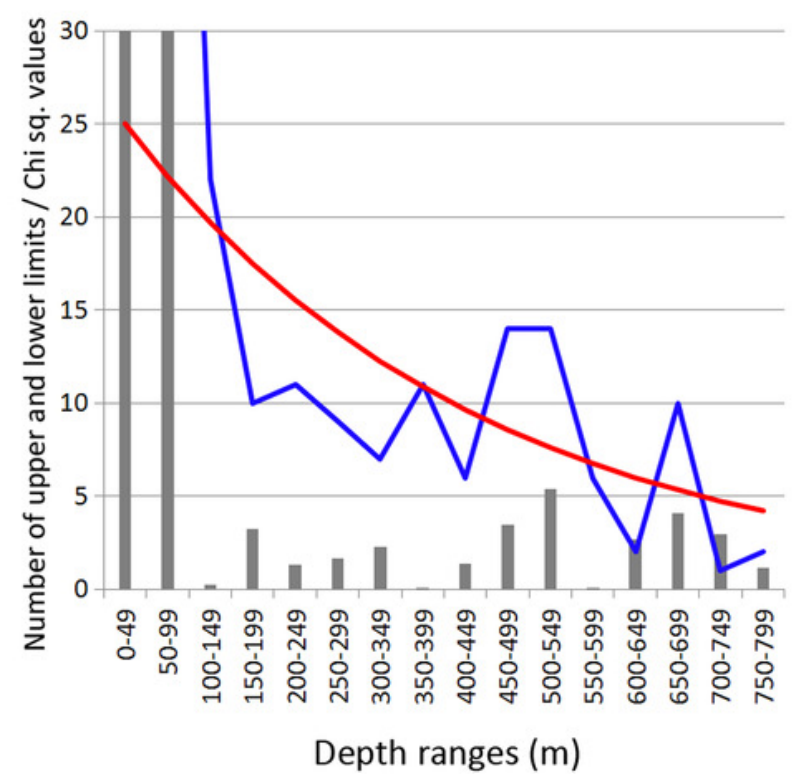

B

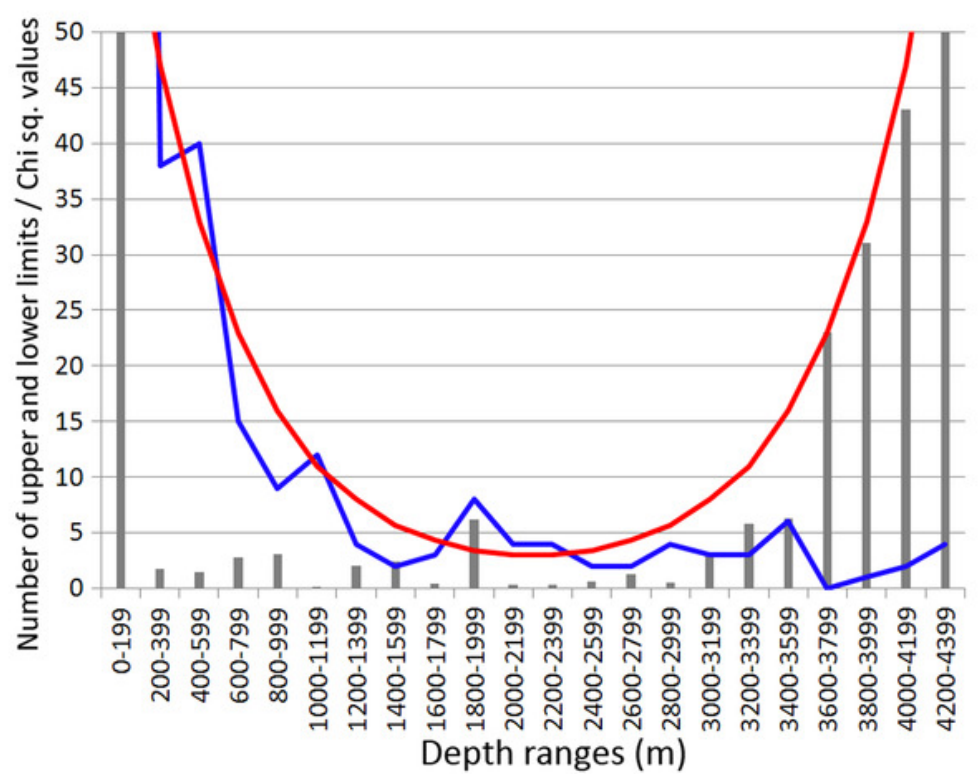


Figure 6

Fig. 6. Distribution of upper and lower vertical limits in species of Echinodermata.

Observed limits are coloured in blue; expected - in red; grey bars indicate Chi sq. values. A upper $800 \mathrm{~m}$ divided into 50-m intervals; B - entire depth range, divided into 200-m intervals.

A

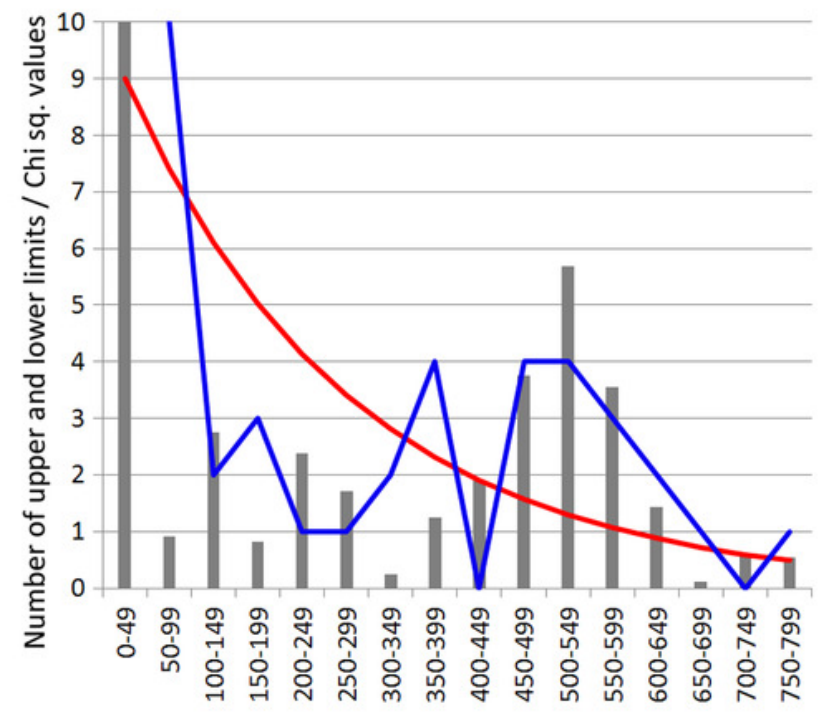

Depth ranges $(\mathrm{m})$
B

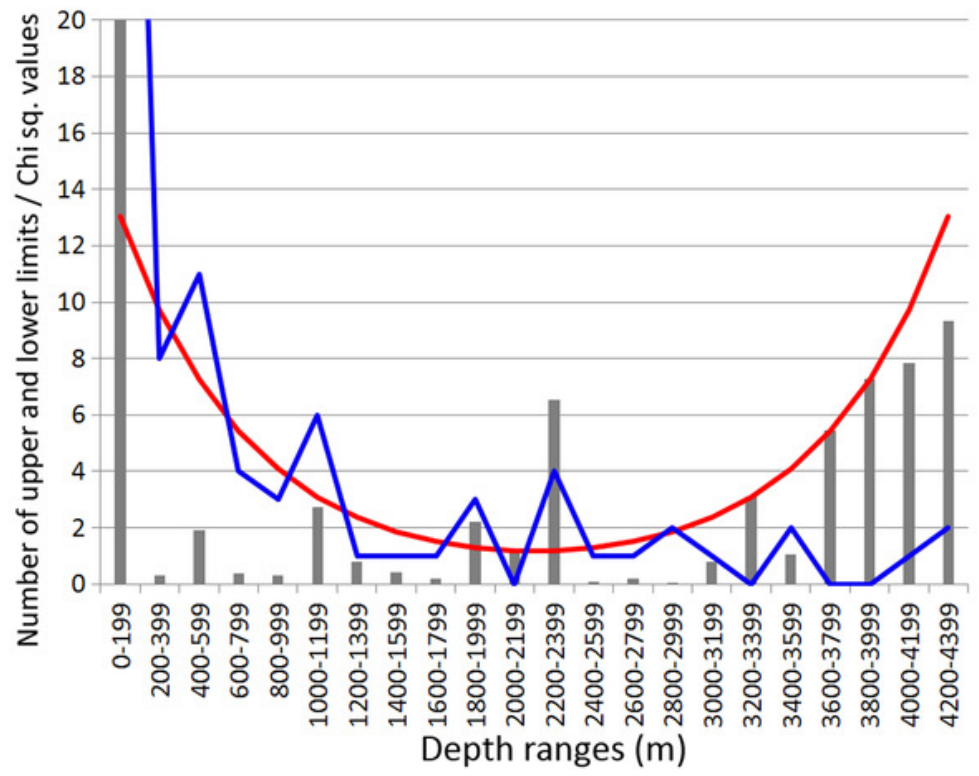


Figure 7

Fig. 7. Distribution of stations by depth.

A - upper 800 m divided into 50-m intervals; B - entire depth range, divided into 200-m intervals.

A

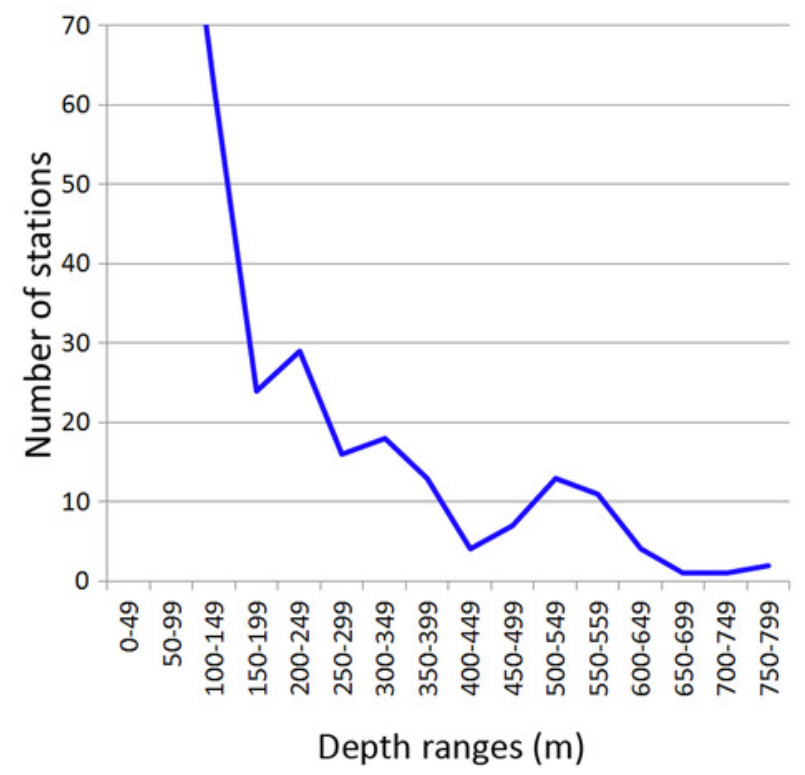

B

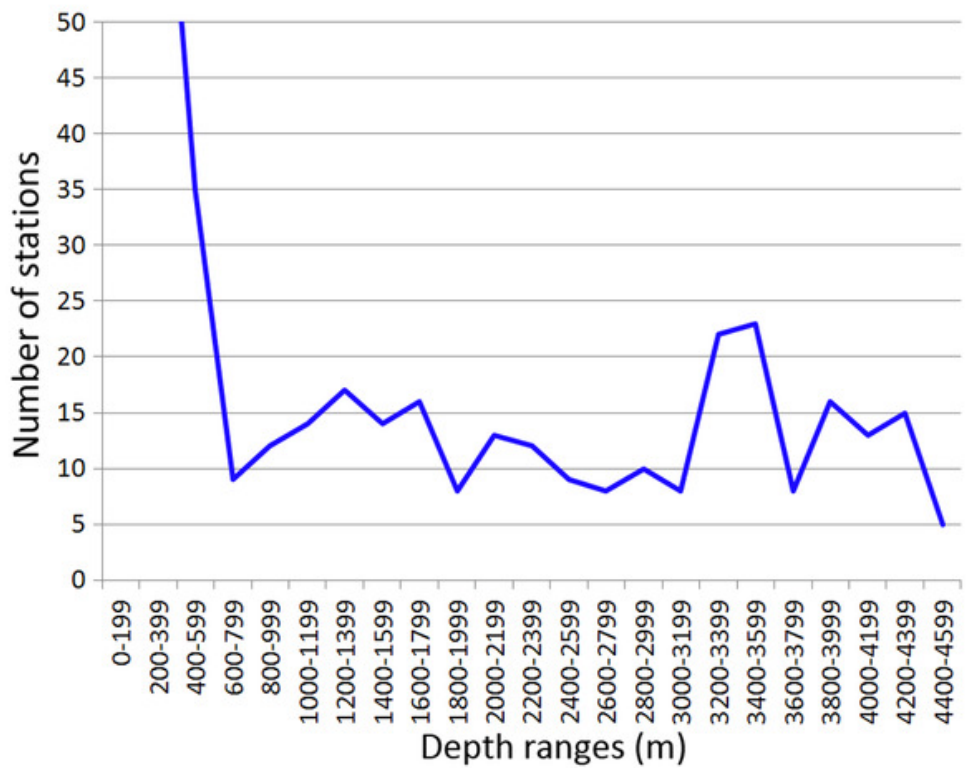


Figure 8

Fig. 8. Combined distribution of the upper and lower species vertical limits in Annelida, Crustacea and Echinodermata.

Observed limits are coloured in blue; expected - in red; grey bars indicate Chi sq. values. A upper 800 m divided into 50-m intervals; B - entire depth range, divided into 200-m intervals.

A

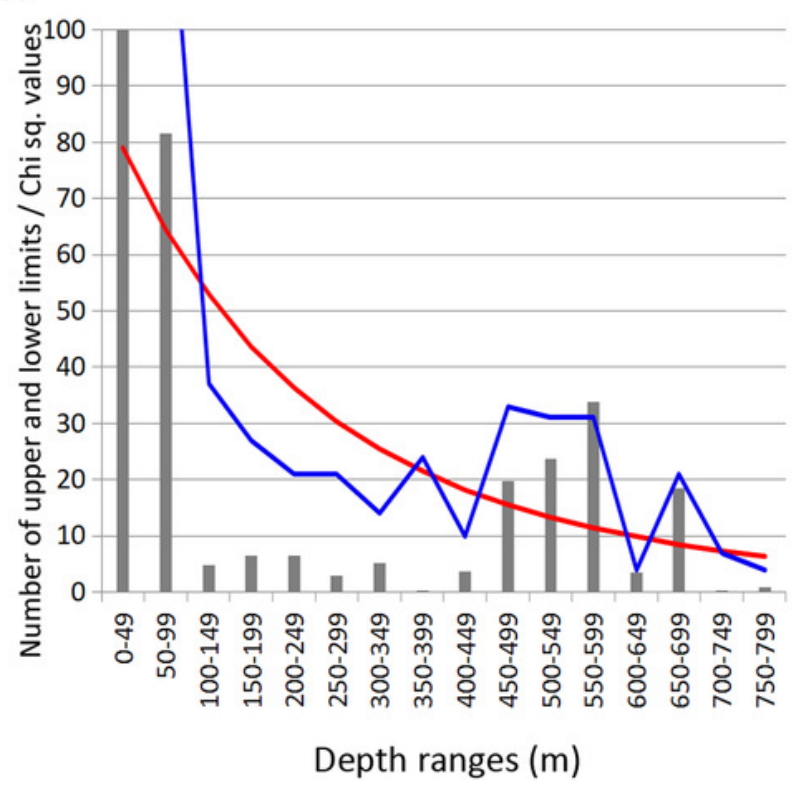

B

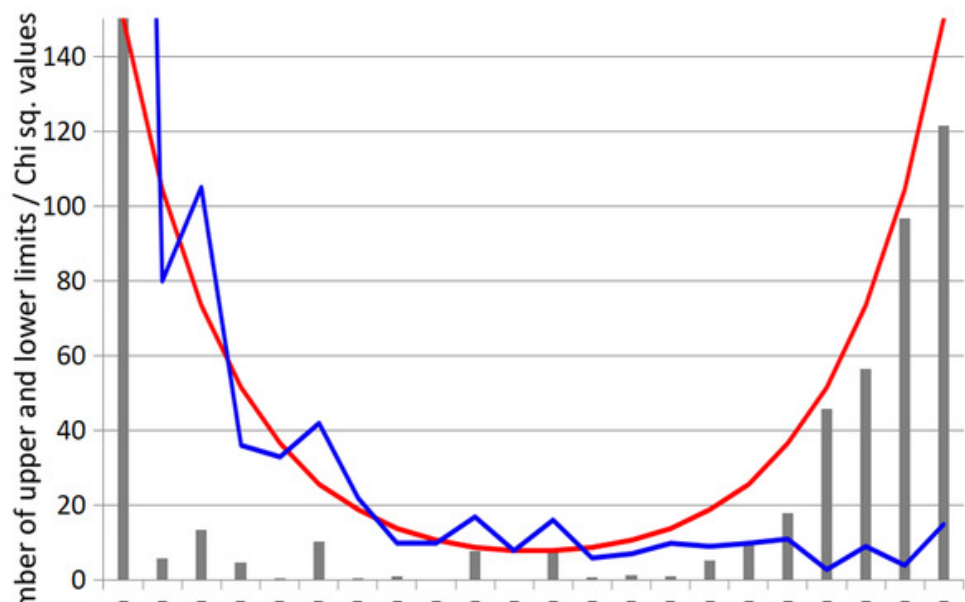

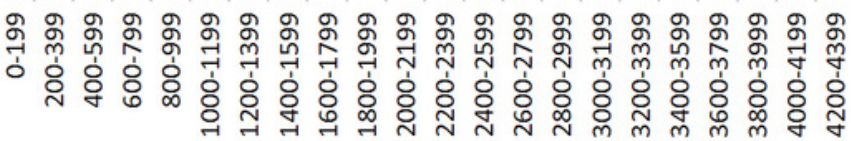
Depth ranges $(\mathrm{m})$ 
Figure 9

Fig. 9. Comparison of vertical boundaries in Annelida, Crustacea and Echinodermata revealed in our study with published data on other regions.

Black colour indicates significant concentrations of the upper and lower vertical limits of species ranges. Grey colour indicates statistically insignificant concentrations.

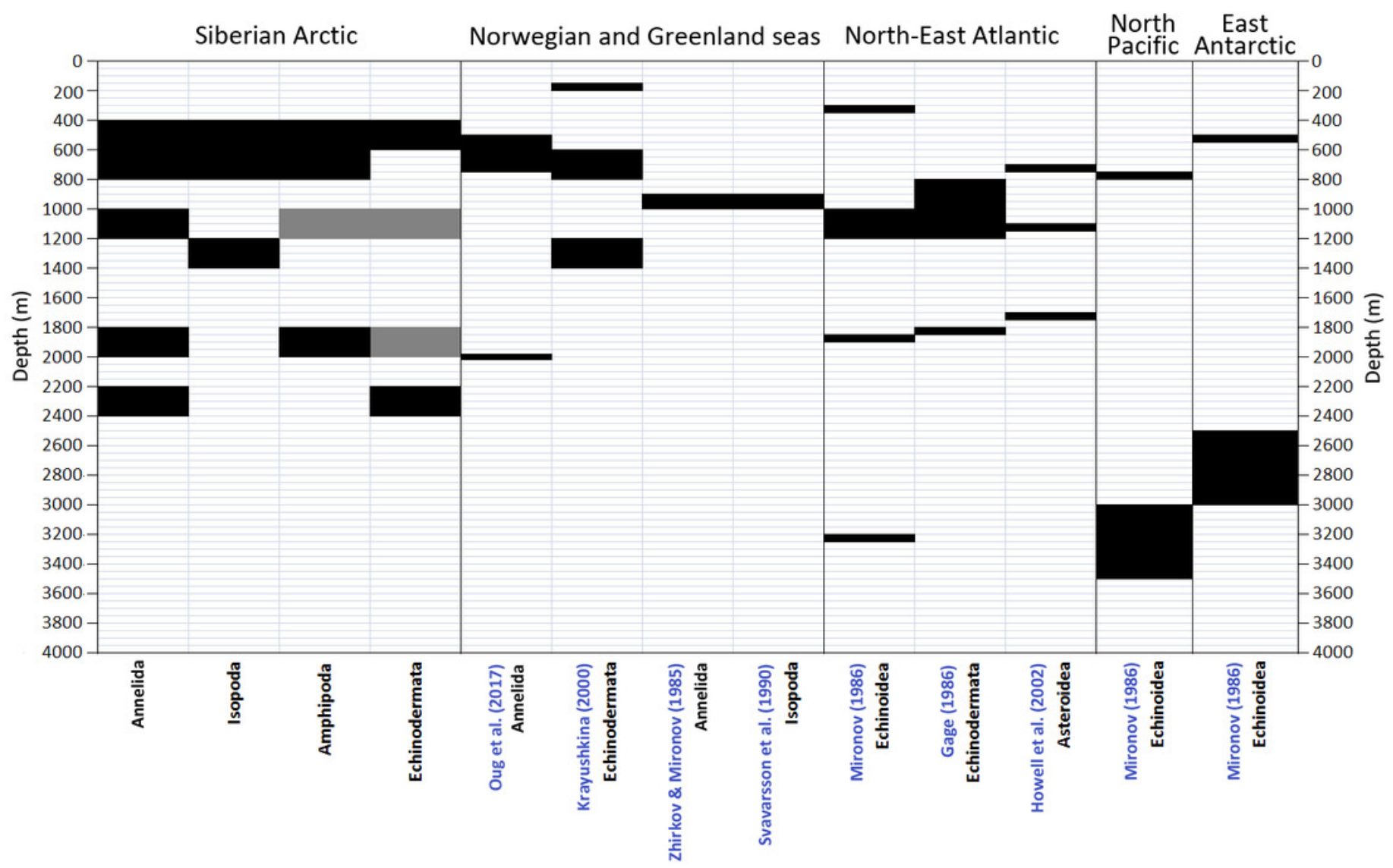




\section{Figure 10}

Fig. 10. Scheme of vertical zonation of benthic fauna distribution in the Siberian Arctic (based on species vertical ranges).

Examples of characteristic species: 1 -Branchiomma arctica; 2 -Leptasterias groenlandica; 3 -Ampelisca macrocephala; 4 -Neohela monstrosa; 5 -Melinnopsis arctica; 6 -Bathybiaster vexillifer; 7 -Elpidia heckeri; 8 -Ymerana pteropoda; 9 -Liljeborgia polosi. (Photographs of A. Vedenin). Dashed lines indicate approximate depths of corresponding boundaries outside the Arctic Ocean: upper line (green) - the boundary at $\sim 200 \mathrm{~m}$ (sublittoral/bathyal), bottom line (yellow) - the boundary at $\sim 3000 \mathrm{~m}$ (bathyal/abyssal).

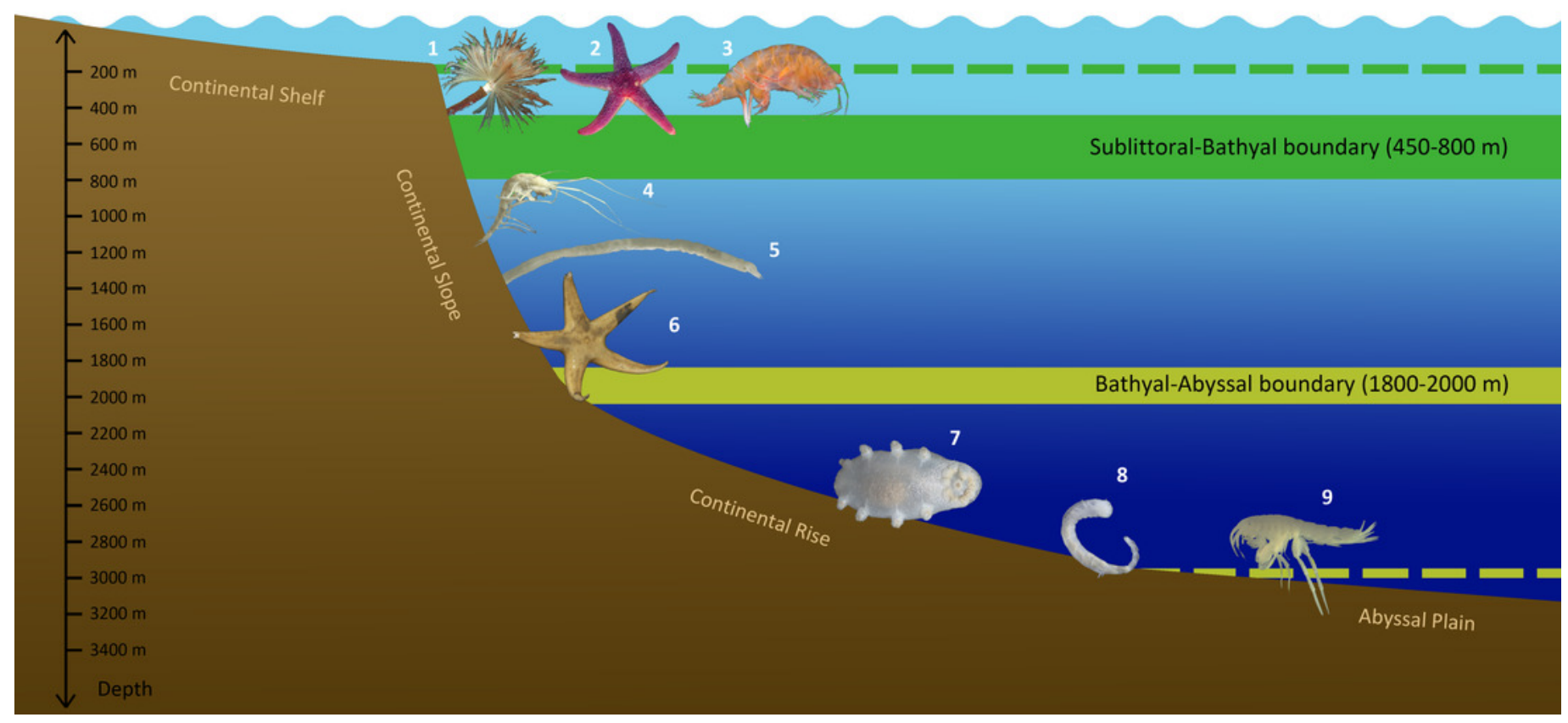




\section{Table $\mathbf{1}$ (on next page)}

Table 1. Summarized upper and lower species vertical limits in different taxa of Crustacea per 200-m depth increments 
Table 1. Summarized upper and lower species vertical limits in different taxaof Crustacea per 200-m depth increments.

\begin{tabular}{|c|c|c|c|c|c|c|c|c|c|c|c|c|c|c|c|c|c|c|c|c|c|c|}
\hline $\begin{array}{c}\text { Crustacea } \\
\text { taxon }\end{array}$ & & & & & & $u m b$ & $r$ of & & nd & Ner & nti; & limi & wit & & $-m o$ & $n+h$ & tery & & & & & \\
\hline & 음 & 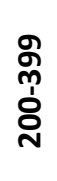 & 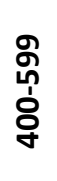 & $\begin{array}{l}\text { જ } \\
\text { †े } \\
\text { ठํ }\end{array}$ & 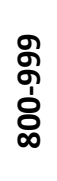 & $\begin{array}{l}\text { g } \\
\text { 국 } \\
\text { ㅇㅇㅇ } \\
\text { 임 }\end{array}$ & 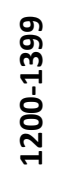 & 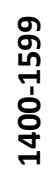 & 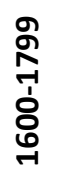 & 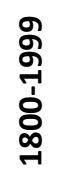 & 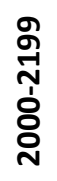 & 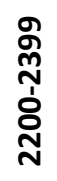 & 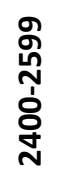 & 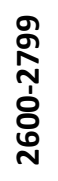 & 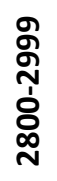 & 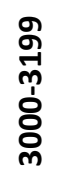 & 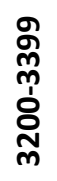 & 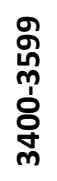 & 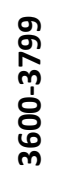 & 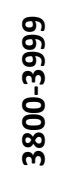 & 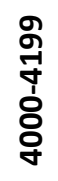 & 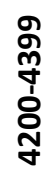 \\
\hline Cirripedia & 6 & 1 & 1 & 2 & & 2 & & & 1 & & & 1 & & & & & & & & & & \\
\hline Jecapoda & 13 & 4 & 6 & 2 & 4 & & & 2 & & & & 2 & & & 1 & & & 1 & & & & 1 \\
\hline Vysidacea & 14 & 3 & 2 & 2 & 1 & 2 & & 4 & & 1 & & 2 & 1 & & & 2 & & 1 & & & & 1 \\
\hline Jumacea & 40 & 9 & 7 & 3 & 2 & 2 & 1 & & 1 & & 1 & 3 & 1 & & 1 & & & 1 & & & & \\
\hline Tanaidacea & 6 & & 1 & & & & 1 & & & 2 & 2 & & & & & 1 & 3 & & & & & \\
\hline
\end{tabular}

Number of upper and lower vertical limits within 50-m depth intervals (the upper $800 \mathrm{~m}$ )

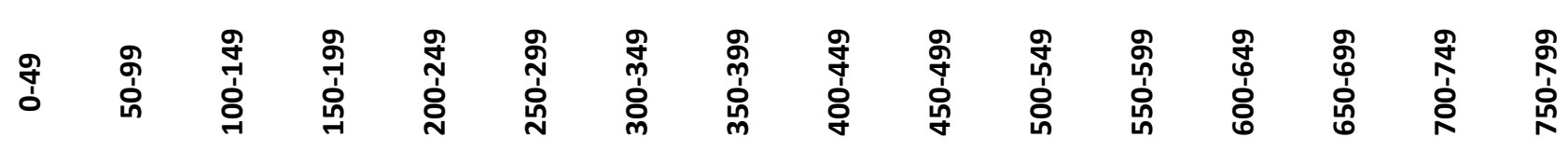

\begin{tabular}{|c|c|c|c|c|c|c|c|c|c|c|c|c|c|c|}
\hline Cirripedia & 6 & & & & & & 1 & & & 1 & & & 2 & \\
\hline Decapoda & 11 & 1 & & & 1 & 4 & & & 3 & 3 & & 1 & 1 & \\
\hline Mysidacea & 10 & 2 & & 2 & 2 & 1 & & 1 & 1 & & & 1 & & 1 \\
\hline Cumacea & 30 & 7 & 1 & 1 & 4 & 3 & 2 & 1 & 4 & 1 & 1 & 2 & 1 & \\
\hline Tanaidacea & 4 & 1 & 1 & & & & & & & & 1 & & & \\
\hline
\end{tabular}




\section{Table 2 (on next page)}

Table 2. Spearman ranked correlation values between the number of stations taken at different depths and the number of upper and lower vertical limits in species of Annelida, Crustacea and Echinodermata. 
Table 2. Spearman ranked correlation values between the number of stations taken at different depths and the number of upper and lower vertical limits in species of Annelida, Crustacea and Echinodermata.

\begin{tabular}{|c|c|c|c|c|}
\hline \multirow{2}{*}{$\begin{array}{l}\text { Taxon, correlated with } \\
\text { number of stations }\end{array}$} & \multicolumn{2}{|c|}{ 50-m intervals for upper $800 \mathrm{~m}$} & \multicolumn{2}{|c|}{$200-m$ intervals for entire depth range } \\
\hline & $\mathbf{R}$ & $p$ & $\mathbf{R}$ & $p$ \\
\hline Annelida & 0.60 & 0.0137 & 0.43 & 0.0449 \\
\hline Isopoda & 0.52 & 0.0380 & 0.48 & 0.0222 \\
\hline Amphipoda & 0.74 & 0.0010 & 0.41 & 0.0577 \\
\hline Echinodermata & 0.58 & 0.0197 & 0.27 & 0.2273 \\
\hline SUM & 0.69 & 0.0029 & 0.52 & 0.0131 \\
\hline
\end{tabular}

3 